Araştırma Makalesi

\title{
Almanya İçin Alternatif Partisi'nin Göçmen Karşıtı Propaganda Faaliyetlerini 2017 Alman Federal Seçimleri Üzerinden Okumak
}

\author{
Caner Çakı (Arş. Gör.) \\ İnönü Üniversitesi İletişim Fakültesi \\ caner.caki@inonu.edu.tr \\ Hasan Topbaş (Dr. Öğr. Üyesi) \\ İnönü Üniversitesi İletişim Fakültesi \\ hasan.topbas@inonu.edu.tr
}

Başvuru Tarihi: 07.02.2018

Yayına Kabul Tarihi: 30.05.2018

Yayınlanma Tarihi: 30.07.2018

Öz

2010 yılının sonlarından itibaren başlayan Arap Baharı ile birlikte Afrika ve Asya kıtalarındaki Müslüman ülkelerden Avrupa Birliği üyesi ülkelere yönelik büyük bir göç dalgası yaşanmıştır. Almanya bu göç dalgasından en çok etkilenen ülkelerin başında yer almaktadır. Bu süreçte, Almanya için Alternatif (Alternative für Deutschland, AfD) adında göçmen karşıtı politikaları ile ön plana çıkan aşırı sağ eğilimli bir parti 2013 yılında Almanya'da kuruldu. 2017 yılının Eylül ayında yapılan Alman Federal Seçimleri'nde AfD, İkinci Dünya Savaşı'ndan sonra Almanya'da aşırı sağ eğilimli siyasi partilerin hiç birinin elde edemediği \%12,6'lık oy oranı ile seçimde üçüncü parti olmayı başardı. Bu çalışmada, kuruluşunun dördüncü yılında seçimlerde Almanya'nın en büyük üçüncü partisi olan AfD'nin başarısında, uyguladığı propaganda faaliyetlerinin rolü açıklanmaya çalışılmıştır. Çalışmada amaçlı örneklem metodu kullanılarak belirlenen AFD’nin 2017 Alman Federal Seçimleri'nde kullandığı göçmen karşıtı üç propaganda afişi ünlü İsviçreli Dil Bilimci Ferdinand de Saussure'ün Göstergeler Sistemi temelinde nitel araştırma yöntemlerinden göstergebilimsel analiz yöntemi kullanılarak incelenmiştir. Çalışma kapsamında incelenen propaganda afişleri AfD'nin resmi web sitesinden elde edilmiştir. Elde edilen bulgular çerçevesinde, propaganda posterlerinde AfD'nin, Saussure'ün gösterilen boyutunda, Almanya'nın göçmenlere ihtiyaç duymadığı ve gelecek olan göçmenlerin Almanya'daki mevcut düzeni yıkmaya çalışacağı algıları üzerinden propaganda faaliyetini yürüttüğü gözlemlenmiştir.

Anahtar Kelimeler: Propaganda, Göçmenler, AfD. 


\title{
The Analysis of the Propaganda Activities Against Immigrants of the Alternative for Germany Party in 2017 German Federal Elections
}

\author{
Caner Çakı (Res. Asst.) \\ İnönü University Faculty of Communication \\ caner.caki@inonu.edu.tr \\ Hasan Topbaş (Asst. Prof. Dr.) \\ İnönü University Faculty of Communication \\ hasan.topbas@inonu.edu.tr
}

Date Received: 07.02.2018

Date Accepted: 30.05 .2018

Date Published: 30.07 .2018

\begin{abstract}
With the Arab Spring since the end of 2010, there has been a massive migration of Muslims from Africa and Asia to the countries of the European Union. Germany is one of the the countries most affected by this wave of migration. In this process, an extreme right-wing party, founded in Germany in 2013, has come to the forefront in Germany, with an anti-immigrant policy called Alternative for Germany (AfD). In the German Federal Elections held in September 2017, AfD succeeded to be third party , with $12.6 \%$ of the vote, which none of the extreme right-wing political parties in Germany had achieved since Second World War. In this study, it was tried to explain the role of the propaganda activities that AfD succeeded in becoming the third biggest party of Germany in the fourth year of its foundation. For this purpose, three antiimmigrant propaganda posters of AFD, which were determined using the purposeful sampling method used in the 2017 German Federal Elections, were examined using the Linguist Swiss Ferdinand de Saussure's Indicators System. The propaganda posters analyzed within the scope of the study were obtained from the official web site of the AfD. Within the findings obtained, it was observed that in the propaganda posters, the AfD carried out propaganda activities, showing that Germany does not need immigrants and the immigrants will try to destroy the existing order in Germany in the frame of Saussure 's signified
\end{abstract}

Keywords: Propaganda, Immigrants, AfD. 


\section{Giriş}

İkinci Dünya Savaşı'nın ardından Almanya uzun yıllar Avrupa Birliği üyesi ülkeler içerisinde en çok göç alan ülkelerin başında gelmiştir. Almanya'daki göçmen nüfusun artışı, dolaylı olarak göçmen karşıtı aşırı sağ grupların da orta çıkmasına yol açmıştır. Göçmen karşıtı bu hareketler ekseriyetle, Nazilerin devamı niteliği olarak addedilen Neo-Nazi fraksiyonlar tarafından yönetilmiştir. Bu gruplar göçmenlere karşı gerçekleştirilen cinayet ve kundaklama eylemleri ile Almanya'da adlarını sıkça söz ettirseler de, Bundestag'da (Alman Federal Meclisi) önemli bir siyasi nüfuz hiç bir zaman elde edememiştir.

Bu süreç, 2017 yılının Eylül ayında yapılan Alman Federal Seçimleri'ne kadar devam etmiş̧tir. Bu seçimlerde ilk defa göçmen karşıtı, aşırı sağ bir parti AfD (Alternative für Deutschland / Almanya için Alternatif), Almanya>nın önde gelen siyasi partileri FDP (Freie Demokratische Partei /Hür Demokrat Parti), Sol Parti (Die Linke) ve Yeşiller'i (Die Grünnen) geride bırakarak Bundestag'ın üçüncü partisi olmayı bașarmıștır. AfD’nin aldığı seçim zaferi, Avrupa kamuoyunda göçmen karşıtı politikaların tekrar gündeme gelmesine yol açmıştır.

$\mathrm{Bu}$ çalışmada, kuruluşunun dördüncü yılında Almanya'nın en büyük üçüncü partisi olmayı başaran AfD’nin başarısında, uyguladığı propaganda faaliyetlerinin rolü açıklanmaya çalışılmıştır. Çalışmada amaçlı örneklem metodu kullanılarak belirlenen AFDınin 2017 Alman Federal Seçimleri»nde kullandığı göçmen karşıtı üç propaganda afişi ünlü İsviçreli Dil Bilimci Ferdinand de Saussuresün Göstergeler Sistemi temelinde nitel araştırma yöntemlerinden göstergebilimsel analiz yöntemi kullanılarak incelenmiştir. Çalışma kapsamında incelenen propaganda afişleri AfDınin resmi web sitesinden elde edilmiștir.

Göstergebilimsel analiz yöntemi, reklamlar, filmler, kartpostallar gibi pek çok farklı alanın analiz edilmesinde kullanılmaktadır. Nitekim, son yıllarda alanda yapılan çalışmalar incelendiğinde, göstergebilimsel analiz yöntemi üzerine önemli çalışmaların yapıldığı gözlemlenmiştir. Örneğin, Tanyeri Mazıcı ve Çakı (2018) «Adolf Hitler'in Korku Çekiciliği Bağlamında Kamu Spotu Reklamlarında Kullanımı» adlı çalışmada Hitler konulu reklamlar üzerinden, Zorlu ve arkadaşları (2017) "Türk Sinemasında Nazizm İdeolojisi:'Kırımlı' Filmi ve Göstergebilimsel Analizi” adlı çalışmada Kırımlı adlı film üzerinden, Işık ve Eşitti (2015) “I. Dünya Savaşı Propaganda Afişlerinde Kadın Temsillerinin Toplumsal Cinsiyet Bağlamında Göstergebilimsel İncelenmesi” adlı çalıșmada ise Birinci Dünya Savașı Propaganda afișleri üzerinden göstergebilimsel analiz yöntemini kullanılarak incelemelerde bulunmuştur.

Çalışma kapsamında yapılan kapsamlı literatür taraması sonucunda 2017 Alman Federal Seçimleri'nde büyük bir başarı elde eden AfD üzerine siyasal kampanya ve propaganda kavramları üzerinden herhangi bir çalışmanın yapılmadığı gözlemlenmiştir. Alanda konuyla ilgili boşluğun oluşması sonucu, bu çalışmada AfD’nin göçmen karşıtı propaganda faaliyetleri 2017 Alman Federal Seçim dönemi özelinde incelenmiştir. Çalışmanın teorik bölümünde ilk olarak Almanya'daki siyasi partilerin göçmenlere bakışı hakkında bilgi verilmektedir. Ardından göstergebilimsel yöntem ve Saussure`ün Göstergeler Modeli açıklanmaya çalışılmıştır.

Çalışmanın uygulama bölümünde ise, AfD’nin 2017 Alman Federal Seçimleri'nde kullandığı göçmen karşıtı propaganda afişleri göstergebilimsel analiz yöntemi 
kullanılarak analiz edilmiş ve elde edilen bulgular çerçevesinde AfD’nin göçmen karşıtı propagandasının temelleri açıklanmaya çalışılmıştır.

\section{Almanya'daki Siyasi Partilerin Göçmenlere Bakışı}

Çalışmanın bu bölümünde 2017 Federal Alman Seçimleri`nde \%5^lik seçim barajını geçen ve Alman Federal Meclisiınde temsil edilme hakkı elde eden 6 siyasi partinin (CDU, SPD, AfD, FDP, Sol Parti, Birlik 90/Yeşiller) göçmenlere karşı politikaları açıklanmaya çalışılmıştır.

\subsection{CDU (Hıristiyan Demokrat Birliği)}

Hıristiyan Demokrat Birliği (CDU, Christlich Demokratische Union Deutschlands) Nazi Almanyası'nın teslim olmasından yaklaşık 2 ay sonra 26 Haziran 1945 tarihinde kuruldu (Bösch, 2002, 14). CDU ideoloji olarak, merkez sağ eğilimli, Hıristiyan Demokrat ve liberal muhafazakar bir siyasi partidir (www.cdu.de). 1949 yılında Federal Almanya'nın kurulmasından itibaren ülkede belirli aralıklarla en uzun süre iktidarda kalan parti olmuştur. 2005 yılından beri partinin genel başkanı Angela Merkel, Alman Şansölyesi (Kanzlerin) olarak görev almaktadır.

CDU, göçmenlerin entegrasyon sürecini desteklemektedir. CDU, göçmenlerin Almanya'da yaşamak için belirli kriterleri sağlaması gerektiğini savunur. Bu kriterlerin başında göçmenlerin en azından günlük hayatta temel iletişimlerini sağlayacağı düşünülen Avrupa Dil Pasaportu'nda Temel Almanca Bilgisi'ni oluşturan A1 Almanca Yeterliliği'ne sahip olmalarını istemektedir. CDU, AfD'nin aksine Almanya'ya yaşanan göçlerin tamamen durdurulmasını savunmaz. Buna karşın göçün kontrollü bir şekilde gerçekleşmesini destekler. Almanya'da entegrasyon sürecinin en büyük savunucularından biri olan CDU, göçmenlerin çifte vatandaşlık elde etmesine -olağanüstüsü durumlar hariç- karşı çıkar (www.cdu.de).

CDU'nun göçmenlere yönelik politikaları genel manada değerlendirildiğinde, AfD gibi göçmen karşıtı radikal fikirleri olmadığı, göçmenlerin kontrollü bir şekilde Almanya'ya gelip, doğru bir şekilde entegrasyona tabi tutulduğunda "Göçmen Sorunu"nun gerçekleşmeyeceğini desteklemektedir.

\subsection{SPD (Almanya Sosyal Demokrat Partisi)}

Almanya Sosyal Demokrat Partisi (SPD, Sozialdemokratische Partei Deutschlands) 1890 yılında kurulan Almanya'nın en eski siyasal partisidir. SPD, merkez sol bir ideoloji eğilimli sosyal demokrat bir partidir. SPD, belirli aralıklarla Almanya'da iktidar partisi olmuştur (www.spd.de).

SPD, önceki dönemlerde koalisyon ortağı olduğu CDU'nun göçmen politikalarının aksini savunur. SPD, göçmenlerin Almanya'ya girişinin engellenmesinin veya sınırlandırılmasının karşısındadır. Göçmenlerin pek çok şartta Almanya'da nitelikli iş gücü olabileceğini savunmaktadır. Göçmenlerin ülkeden sürülmesinin karşısındadır (www.dw.com).

\subsection{AfD (Almanya İçin Alternatif)}

Almanya için Alternatif (AfD, Alternative für Deutschland), 2013 yılında kurulan ve Alman milliyetçiliği, muhafazakârlık, ekonomik liberalizm gibi ideolojileri içinde barındıran aşırı sağ eğilimli bir siyasi partidir. 2017 Alman Federal Seçimleri'nde temsil edilme hakkı elde eden siyasi partiler içerisinde en genç olanıdır (www.afd.de). 
AfD, göçmenlere yönelik gerektiğinde Alman sınırının kapatılması gerektiğini savunmaktadır. AfD, Müslüman çoğunlukta olan ülkelerden ve Afrika'dan gelen göçmenleri göz önüne alarak, Almanya'daki göçmen nüfusun orantısız artışının Alman toplumsal ve kültürel yaşamını olumsuz yönden etkileyeceğine inanır. $\mathrm{Bu}$ açıdan göçmen sayısının Almanya'da mutlaka denetim altına alınmasını talep eder (www.dw.com).

AfD, 2017 Alman Federal Seçimleri'nden sonra mecliste temsil edilen siyasi partiler içerisinde en sert göçmen karşıtı politikalara sahip parti durumdadır. AfD, siyasetini tamamen göçmen karşıtı politikalar üzerine yürütmekte ve Almanya'da göçmen karşıtı seçmenlerin oylarını elde etme eğilimindedir.

\subsection{FDP (Hür Demokratik Parti)}

Hür Demokratik Parti (FDP, Freie Demokratische Partei) 1948 yllında kurulan liberalizm ideolojisine sahip merkez sağ partidir. Almanya'da kurulan koalisyon hükümetlerinin küçük ortağı olarak pek çok defa iktidarda yer almıştır (www.fdp.de).

FDP, göçmenlere karşı alınan sıkı tedbirleri desteklemez. Buna karşın SPD kadar göçmenlere yönelik ılımlı bir politikaya da sahip değildir. FDP, Almanya'ya yönelik göçün sınırlandırılmasına karşı çıkmaktadır (www.dw.com).

\subsection{Sol Parti}

Sol Parti (Die Linke) 2007 yılında kurulan demokratik sosyalist ve sol popülist bir siyasî partidir (www.die-linke.de). Sol parti, Birlik 90/Yeşiller Partisi ile birlikte Alman Meclisi'nde yer alan göçmen yanlısı tutumlarıyla bilinen iki siyasi partiden biridir. Almanya'da göçmenlere karşı politikaların mümkün olduğun esnetilmesini, göçmenlerin yurtdışında yaşayan tüm akrabalarının da Almanya'da yaşama hakkı elde etmesini ve sınır dışı edilmenin tamamen durdurulmasını istemektedir (www.dw.com).

\subsection{Birlik $90 /$ Yeşiller}

Birlik 90/Yeşiller (Bündnis 90/Die Grünen) 1980 yılında kurulan merkez sol görüşlü bir partidir (www.gruene.de). Birlik 90/Yeşiller, Sol Parti gibi Almanya'ya ne kadar göçmenin geleceğinin sınırlandırılması ve bir kota konulmasına yönelik uygulanan üst sınır politikasına karşı çıkar. Göçmenlerin ailelerinin de hiç bir şarta tabi tutulmadan Almanya'da ikamet etme haklarının verilmesini talep eder (www.dw.com).

\section{NPD'den AfD'ye Almanyadaki Aşırı Milliyetçi Gruplar}

30 Nisan 1945 yılında Nazi Almanya'sının Devlet Başkanı Adolf Hitler'in intiharı ve hemen ardından 7 Mayıs 1945'de Almanya'nın İkinci Dünya Savaşı'ndan kayıtsız şartız teslim olarak ayrılması (Liddell Hart, 2015, 945), Almanya'daki aşırı sağ eğilimli tek parti yönetiminin son bulmasına ve 1949 yılına kadar devam edecek olan Müttefik Devletlerin işgalinin başlamasına yol açtı. 1949 yılında ise Almanya, Batı Almanya (Federal Almanya) ve Doğu Almanya (Demokratik Almanya) olarak iki devlet haline geldi (Kissinger, 2010, 442).

Almanya'da 1945 yılında, Nazi Almanyası'nın tek partisi durumunda olan NSDAP'nin (Nasyonal Sosyalist Alman İşçi Partisi) Müttefiklerce dağıtılıp, yasaklanmasında sonra uzun bir süre aşırı milliyetçi sağ fraksiyonlar Almanya'da varlık gösteremedi. Bunun altında yatan iki önemli nedenden biri, savaşın galibi Müttefikler tarafından 
Nazilerin tekrar ortaya çıkmasını engellemek için Almanya'da alınan yaptırımlar ikincisi ise 1949 yılında Batı Almanya'nın Başbakanı olan ve 1963 yılına kadar bu görevi sürdüren Kondrad Adenauer'ın Almanya'da uyguladı̆̆ı bütünleştirici politikası idi (Efkan, 1997, 91). Doğu Almanya'nın 1990 yılına kadar komünist ideoloji altındaki Sovyet denetiminde olması her türlü milliyetçi sağ fraksiyonun ülkede resmi olarak ortaya çıkmasını önledi. Müttefik Devletlerin denetimindeki Batı Almanya'da ise sağ gruplar için durum göreceli olarak daha iyi bir durumdaydı.

1964 yılında kurulan aşırı milliyetçi Almanya Ulusal Demokratik Partisi (NPD, Nationaldemokratische Partei Deutschlands) (www.npd.de), Almanya'da seçimlerde aşırı sağ milliyetçi grupların, İkinci Dünya Savaşı'ndan sonraki en büyük başarılarını elde etmeyi başardı. NPD’nin başarısı partinin kısa sürede tüm popülaritesini de arttırdı(Efkan, 1997,96-97).NPD seçimdekazandığıbaşarılarına rağmen, göçmenlere karşı nefreti körükleyen politikalarını sürdürmesi ve göçmenlere karşı girişilen şiddet eylemlerinde adının yer alması, partinin geniş kitlelere yayılmasını önledi. İlerleyen süreçte NPD’nin tüm seçmenleri kucaklayan söylemlere yönelmemesi partinin eski gücüne kaybetmesine yol açtı (Efkan, 1997, 106). NPD'nin haricindeki diğer aşırı sağ fraksiyonlar Batı ve Doğu Almanya'nın birleştiği 1990 yılından sonra da önemli bir varlık gösteremedi. Bu dönemde, Alman Basını'nda aşırı sağ milliyetçi grupların ismi, yalnızca göçmenlere karşı giriştikleri şiddet eylemlerinde anıldı. Bu eylemleri gerçekleştirenler de ekseriyetle Neo-Nazi gruplar olarak sunuldu.

Bu süreç, 2013 yılında AfD’nin kurulmasına kadar devam etti. 2013 Alman Federal Seçimleri'nde Alternatif für Deutschland Partisi aldığı \%4,7'lik oy oranı ile NPD'den sonra İkinci Dünya Savaşı'ndan sonraki süreçte Almanya'da aşırı milliyetçi partiler içerisinde en önemli başarıyı elde eden siyasi güç oldu (Niedermayer, 2015, 175). Seçim dönemlerinde yürüttüğü açık, anlaşılır ve bilgilendirici propaganda faaliyetleri AfD'nin başarısındaki en büyük nedenlerin başında yer aldı (Schmitt-Beck, 2014, 111). 2010 Arap Baharı ile patlak veren "Göçmen Krizi" ile 2009 yılında ortaya çıkan "Euro Krizi"lerinin AfD tarafından doğru okunarak, propaganda faaliyetlerinde başarılı bir şekilde kullanılması, AfD’nin seçimlerde zafer kazanmasına yol açtı. Bu açıdan, AfD'nin gündemindeki temel iki konunun ekonomik liberalizm (Bebnowski, $2015,5)$ ve göçmenlere yönelik alınması gereken tedbirler (Grimm, 2015, 271) olduğu görülemektedir. Özellikle AfD, 2017 Alman Federal Seçimleri'nde göçmen karşıtı söylemlere retoriğinde oldukça sık yer verdi (Schmitt-Beck, 2017, 138). Nihayetinde 2017 Alman Federal Seçimleri'nde AfD, \%12,6’lı bir oy oranı ile Alman Federal Meclisi'nde üçüncü parti olmayı başardı.

Bu çalışmada AfD’nin 2017 Federal Alman Seçimleri'nde kullandığı iki temel başlıktan biri olan "Göçmen Krizi"nin seçimlerde propaganda posterlerine nasıl yansıtıldığı ortaya konulmaya çalışılmıştır.

\section{Ferdinand de Saussure ve Göstergeler Modeli}

Göstergebilim diğer adıyla semiyoloji (Rıfat vd, 2010, 42), son yıllarda özellikle sosyal bilim alanında kullanılan önemli bir nitel araștırma yöntemidir. Göstergebilim gazete haberi, dergi röportajı, kitap bölümü gibi yazılı bir metnin veya TV dizisi, sinema filmi gibi görsel bir öğenin açık ve herkes tarafından kabul edilen anlamının dışında, onun altında yatan ve herkes tarafından anlaşılmayan anlamların ortaya çıkarılmasını sağlayan bir bilim dalıdır (Geray, 2014, 164). Göstergebilim, çevremizde bulunan her göstergenin bir iletişim değeri olduğu ve 
bu göstergelerin herkes tarafından bilinen anlamı dışında farklı mesajlar içerebileceğini vurgulamaktadır.

Göstergebilim, 19. yüzyılda İsviçreli Ferdinand de Saussure ve ABD’li Charles Sanders Peirce'ın yapmış olduğu çalışmalar ile ortaya çıkmıştır (Sı̆̆ırcı, 2016, 29). $\mathrm{Bu}$ iki bilim insanı çevremizde dil merkezli göstergelerin anlamlandırılmasına yoğunlaşmış, mevcut konuşma dilinin haricinde, dilin farklı anlamlandırmaları ifade edebileceğini vurgulamıştır.

Bu süreçte özellikle Saussure'ün çalışmaları göstergebilimin modern anlamda ilk eserleri olarak kabul görmektedir. Saussure, göstergebilimi Göstergeler Modeli adını verdiği bir yapı üzerine inşa etmektedir. Bu yapı, gösterge temelinde, gösteren ve gösterilen kavramları üzerine şekillenmektedir. Saussure, göstergeyi, gösteren (ses imgesi) ve gösterilen (kavram) arasındaki birleşimden doğan öğeyi ifade etmek için kullanır (Sığırcı, 2016, 32). Saussure dili bir bütün olarak ele alır ve her göstergenin bir gösteren ve bir gösterilenden oluştuğunu söyler (Kocabay, 2008, 16). Gösteren ile gösterilen arasındaki ilişki bir saymacadır (Guiraud, 2016, 41). Buna karşın, anlamlama gösteren ve gösterileni birleştiren ve sonu gösterge olan bir edimdir (Barthes, 2016, 54). Gösterenler herkes tarafından kabul gören anlamlardır. Örneğin, bir demet çiçek gösteren boyutu ifade ederken, çiçeğin bir kadına sunulması gösterilen boyutta "aşk", "sevgi" ve "evlilik" gibi pek çok farklı gösterilene de işaret edebilmektedir.

Gösteren, göstergenin doğrudan anlamlandırılabilen ve duyumsanabilen parçasıdır. Dilin de işitim imgesini ifade eder (Rıfat, 2013, 97). Gösterilen, ise göstergenin doğrudan anlamlandırılamayan parçasını ifade eder. Göstergenin kavramsal yapısını oluşturur, onun içeriğidir (Rıfat, 2013, 107). Bu açıdan gösteren ve gösterilen bir kağıdın iki yüzü olarak değerlendirilebilmektedir. Her iki kavramda göstergenin temel bütünü olarak görüldügü için birbirlerinden ayrı düşünülemezler.

Saussure'ün ortaya koyduğu göstergebilim kavramı dil üzerine temellenmekteydi. Her ne kadar dil dıșı nesnelerin de yorumlanmasına ve anlamlandırılmasına izin verse de, Saussure'ün göstergebilim anlayıșı ağırlıklı olarak metin incelemeleri üzerine yapılmıştır. Saussure, her dil yetisinin, gösteren ve gösterilen içindeki ilişki üzerinden kurulduğunu söyler. Yani, Saussure'ün ortaya koyduğu algıda gösteren, insanlar tarafından duyulan, gösterilen ise insanlar tarafından ona verilen anlamdır (Sığırcl, 2016, 41). Gösteren çoğu zaman evrensel değerleri ifade ettiği için algılanması kolaydır. Buna karşın gösterilenler kültürden kültüre farklılık arz edebildiği için yorumlanması zor bir süreci ifade edebilmektedir.

Göstergenin çözümlenmesi için, göstergenin belirli bir dizge ve şifre içerisinde olması gerekmektedir. Örneğin, belirli grupların selamlaşma tarzları veya trafik kuralları gibi uzlaşı odaklı davranışlar belirli şifrelere dayanmaktadır (Kocabay, 2008, 18). $\mathrm{Bu}$ şifrelerin çözümlenebilmesi ise kişinin bağlamda yaşananları iyi okuyabilmesi ve onları kültürel paradigmalar içerisinde doğru bir şekilde anlamlandırması ile mümkün olmaktadır.

Bu çalışmada, AfD’nin göçmen karşıtı propaganda afişleri Saussure'ün Göstergeler Modeli temelinde analiz edilmiştir. Propaganda posterlerinde yer alan gösterenlerin hangileri olduğu ve gösterilen boyutta ne ifade ettiği, propagandanın yapıldığı bağlam dikkate alınarak değerlendirilmiştir. Sonuç olarak propaganda posterlerinde 
Alman seçmenlere verilmek istenen göçmen karşıtı mesajlar göstergebilimin çatısı altında ortaya konulmaya çalışılmıştır.

\section{AfD’nin Göçmen Karşıtı Propaganda Posterlerinin Göstergebilimsel Analizi}

Çalışmanın bu bölümünde, 2017 Alman Federal Seçimleri`nde kullanılan, amaçlı örneklem metodu kullanılarak belirlenen AFDınin göçmen karşıtı üç propaganda afişi ünlü Dil Bilimci İsviçreli Ferdinand de Sauusure`ün Göstergeler Modeli kullanılarak incelenmiştir.

\section{1. Çalışmanın Yöntemi}

Çalışma kapsamında örneklem olarak belirlenen AfDınin göçmen karşıtı propaganda posterleri nitel araştırma yöntemlerinden göstergebilimsel analiz yöntemi kullanılarak incelenmiştir. İsviçreli Ferdinand de Saussure ün Göstergeler Modeli temelinde incelenen propaganda posterleri, gösteren ve gösterilen anlamları temelinde analiz edilmiştir.

\section{2. Çalışmanın Amacı}

Çalışmada, Almanya'da göçmen karşıtı politikaları ile 2017 Alman Federal Seçimleri'nde üçüncü parti olmayı başaran AfD’nin seçim başarısında seçim dönemi kullandığı göçmen karşıtı propaganda posterlerinin rolü analiz edilmeye çalışılmıştır. Bu amaçla, Avrupa'da Arap Baharı ile birlikte artan göçmen hareketlerinin doğurduğu göçmen karşıtı politikalardan AfD'nin nasıl yararlandığı ortaya çıkarılmaya çalışılmıştır. Çalışmada ayrıca AfD’nin göçmen karşıtı propaganda posterlerinde seçmenlerin zihinlerinde hangi algıları inşa etmeye çalıştığı da açıklanmıştır.

\section{3. Çalışmanın Evreni ve Örneklemi}

Her beş yılda bir yapılan Birleşmiş Milletlerin 2015 dünya göçmen haritasına göre, Arap Baharı'ndan sonra Müslüman ülkelerden göç alan Avrupa Birliği üyesi ülkeler içerisinde en fazla göçmen nüfusa sahip ülke Almanya çalışmada kapmasında incelenmiștir (https://www.un.org).

Tablo 1: Birleșmiş Milletlerin 2015 Verilerine Göre

Dünyada En Fazla Göçmen Nüfusa Sahip İlk Beş Ülke

\begin{tabular}{|c|l|c|}
\hline Sıralama & Ülkeler & Sahip Olduğu Toplam Göçmen Nüfus \\
\hline 1. & Amerika Birleşik Devletleri & $46,627,102$ \\
\hline 2. & Almanya & $12,005,690$ \\
\hline 3. & Rusya & $11,643,276$ \\
\hline 4. & Suudi Arabistan & $10,185,945$ \\
\hline 5. & Birleşik Krallık & $8,543,120$ \\
\hline
\end{tabular}

Kaynak: https://www.un.org/en/development/desa/population/migration/data/estimates2/estimates15.shtml Erişim Tarihi: 04.02.2018.

2017 yılında yapılan Alman Federal Seçimleri'nde üçüncü parti olarak seçilen ve İkinci Dünya Savaşı'ndan sonra Almanya' daki aşırı sağ bir partinin şimdiye kadar elde edemediği bir başarı yakalayan AfD (Almanya için Alternatif) çalıșma kapsamında incelenmiștir (http://www.spiegel.de). Çalışma kapsamında AfD’nin resmi web sitesinden elde edilen ve partinin 2017 Alman Federal Seçimleri'nde kullandığı tüm propaganda posterleri içerisinden doğrudan göçmenleri hedef alan üç propaganda posteri amaçlı örneklem metodu kullanılarak seçilmiş ve çalışmanın örneklemini oluşturmuştur (www.afd.de). 
Tablo 2: 2017 Alman Federal Seçim Sonuçları

\begin{tabular}{|c|l|c|}
\hline Siralama & Partiler & Oy Oranları \\
\hline 1. & CDU & 33 \\
\hline 2. & SPD & 20,5 \\
\hline 3. & AfD & 12,6 \\
\hline 4. & FDP & 10,7 \\
\hline 5. & Die Linke & 9,2 \\
\hline 6. & Die Grünnen & 8,9 \\
\hline
\end{tabular}

Kaynak: http://www.spiegel.de/politik/deutschland/bundestagswahl-2017-alle-ergebnisse-im-ueberblick-a1167247.html// Erişim Tarihi: 04.02.2018.

\section{4. Çalışmanın Sınırıılıkları}

Çalışmada iki temel sınırlılık bulunmaktadır. Çalışmada kapsamında incelenen propaganda afişlerinin yalnızca Sausssure'ün göstergebilimsel metodu üzerinden değerlendirilmesi çalışmanın birinci sınırlılığını oluşturmaktadır. Çalışmada örneklem olarak belirlenen AfD’nin yalnızca propaganda posterleri üzerinden göstergebilimsel analiz yapılması da çalışmanın diğer önemli sınırlılığını meydana getirmektedir. Nitekim gelecek çalışmalarda, AfD’nin propaganda faaliyetlerinin, gazete, radyo, televizyon ve internet gibi farklı iletişim araçları üzerinden analiz edilmesi alana katkı sağlayacaktır.

\section{5. Çalışmanın Önemi}

Çalışma kapsamında yapılan kapsamlı literatür taraması sonucunda 2017 Alman Federal Seçimleri'nde büyük bir başarı elde eden AfD üzerine siyasal kampanya ve propaganda kavramları üzerinden herhangi bir çalışmanın yapılmadı̆̆ı gözlemlenmiştir. Bu açıdan yapılan çalışmanın AfD’nin göçmen karşıtı propaganda faaliyetlerini kapsamlı bir şekilde analiz etmesi ve Almanya'daki aşırı sağ grupların AfD özelinde göçmenlere yönelik düşüncelerinin ortaya konulması bakımından önem taşımaktadır.

\section{6. Çalışmanın Soruları}

Çalışma kapsamında aşağıda belirtilen sorulara yanıt aranmaya çalışılmıştır;

- AfD’nin göçmen karşıtı propaganda posterlerinde kullanılan gösterenler hangileridir?

- AfD’nin göçmen karşıtı propaganda posterlerinde kullanılan gösterilenler hangileridir?

- AfD’nin göçmen karşıtı propaganda posterlerinde genel olarak hangi metaforlar kullanılmaktadır?

- AfD’nin göçmen karşıtı propaganda posterlerinde genel olarak hangi metonimler ile göçmenler temsil edilmeye çalışılmıştır?

- AfD’nin göçmen karşıtı propaganda posterlerinde seçmenlerin zihninde inşa edilmeye çalışılan algılar nelerdir?

\subsection{AfD'nin 2017 Alman Federal Seçimleri'nde Kullandığı Göçmen Karşıtı Propaganda Posterlerinin Göstergebilimsel Analizi}

Çalışmanın bu bölümünde, AFD’nin göçmen karşıtı üç propaganda posteri ("Burkalar" Konulu Propaganda Posteri, "Yeni Almanlar" Konulu Propaganda Posteri, "Renkli Çeşitlilik" Konulu Propaganda Posteri) göstergebilimsel analizi yöntemi kullanılarak incelenmiștir. 


\subsubsection{AfD’nin “Burkalar” Konulu Propaganda Posteri'nin Göstergebilimsel Analizi}

AfD’nin “Burkalar” konu propaganda posterinde, gösterge boyutunda denize doğru yönelen bikini giymiş iki kadın görülmektedir. Kadınlar posterde sırtlarını dönmüş bir vaziyettedir. İki kadının fotoğrafının tam ortasında Almanca "Burkas? Wir steh'en auf Bikinis/ Burkalar mı? Biz bikini giyiyoruz." yazısı bulunmaktadır. Posterin hemen altında ise büyük harfler ile yine Almanca AfD'nin parti sloganlarından biri olan “TRAU DICH DEUTSCHLAND! / INAN ALMANYA!" yazısı bulunmaktadır. Posterin sağ alt bölümünde de AfD'nin parti logosu yer almaktadır.

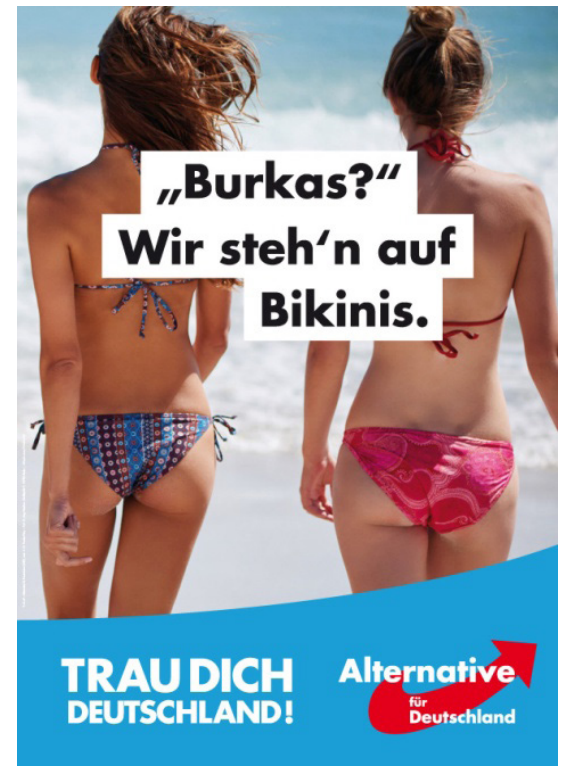

Resim 1: "Burkalar" Konulu Propaganda Posteri

Kaynak: https://www.afd.de/meldungen-bundesverband/partnerportale/ Erişim Tarihi: 04.02.2018.

AfD, propaganda posterinde Burkalar? yazısı ile göçmenleri ifade etmek için bir metonim kullanmıştır. Yani göçmenlere posterde direkt olarak yer verilmemiş onun yerine göçmenleri temsil ettiği düşünülen Burkalar? yazısı kullanılmıştır. Burka ifadesiyle posterde yer alan gösterilen ise göçmenlerdir. Denize doğru ilerleyen iki kadın ise gösterilen boyutta Almanya'nın günlük hayatından bir kesitini ifade etmektedir. Posterde gösteren boyutta kullanılan bikiniler ise gösterilen boyutta burkalara yönelik olarak zitlığı ve karşıtlığ ifade etmektedir. Posterde yazan "Burkalar mı? Biz bikini giyiyoruz." yazısı ile gösterilen boyutta Alman seçmeni üzerinde inşa edilmek istenen algının, Almanlar ile göçmenlerin tamamen farklı oldukları, göçmenlerin Alman toplumuna ait olmadığıdır.

Tablo 3: AfD'nin "Burkalar" Konulu Propaganda Posteri ve Göstergeler Tablosu

\begin{tabular}{|c|c|c|}
\hline \multicolumn{3}{|c|}{ Göstergeler Sistemi } \\
\hline Gösterge & Gösteren & Gösterilen \\
\hline Nesne & Burka & Göçmenler \\
\hline İnsan & İki Kadın & Almanların Günlük Hayatı \\
\hline Nesne & Bikini & Burkalara Olan Karșıtlık \\
\hline
\end{tabular}

\subsubsection{AfD'nin "Yeni Almanlar" Konulu Propaganda Posteri'nin Göstergebilimsel Analizi}

AfD'nin "Yeni Almanlar" konulu propaganda posterinde gösterge boyutunda bir kadın kullanılmıştır. Gösteren, kırlara sırt üstü uzanmıș, yüzünde bir gülümseme olan hamile bir kadındır. Kadının karın bölgesi yarı çıplaktır. Kadının yüzü posterde 
gösterilmemektedir. Diğer yandan sunum kodları içerisinde verilen giyim tarzı spor ve günlük hayattan bir kesiti yansitmaktadır. Posterin hemen üstünde Almanca "'Neue Deutsche?' Machen wir selber. /'Yeni Almanlar mı?' Biz kendimiz yaparız" yazısı yer almaktadır. Posterin hemen altında ise büyük harfler ile yine Almanca AfD'nin parti sloganlarından biri olan "TRAU DICH DEUTSCHLAND! / INAN ALMANYA!" yazısı bulunmaktadır. Posterin sağ alt bölümünde de AfD’nin parti logosu yer almaktadır.

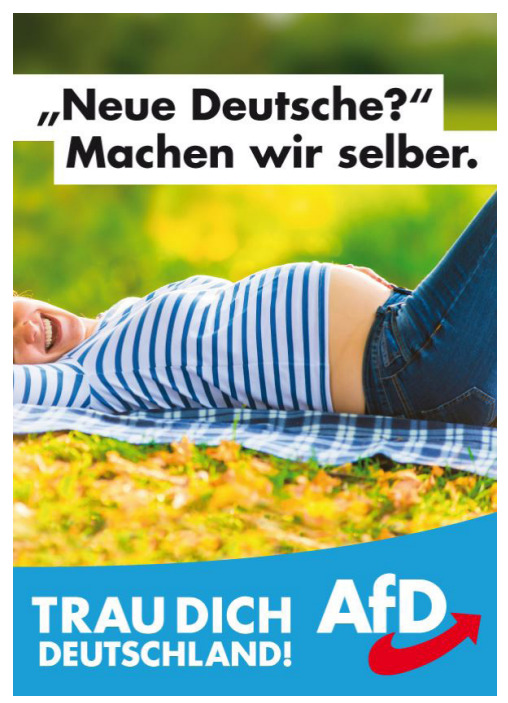

Resim 2: "Yeni Almanlar" Konulu Propaganda PosteriKaynak: https://www. afd.de/meldungen-bundesverband/partnerportale/Erişim Tarihi: 04.02.2018.

Saussure'ün Göstergeler Modeli üzerinden AfD’nin propaganda posterinin doğru bir şekilde okunabilmesi için, propagandanın yapıldığı toplumun, kültürün ve özellikle de bağlamın doğru bir şekilde tanınması ve okunması gerekmektedir. Nitekim, göstergebilimin temel anlayışını oluşturan «parçalar bütünü oluşturur» mantığı içerisinde hareket edildiğinde, tek başına bir anlam ifade etmeyen bölümler, bir arada propagandacının gösterilen boyutunda ana mesajını inşa edebilmektedir.

AfD’nin “Yeni Almanlar” konulu propaganda posterinde gösterilen boyutta kullanılan kadının Alman olduğunu ve Alman toplumunu yansıttığını posterin genelinde verilen ana mesajdan anlamak mümkündür. Hamile kadının gülümseyerek karnını göstermesi ve hemen posterin üzerinde yer alan “'Yeni Almanlar mı?' Biz kendimiz yaparız" yazısı anlamlı bir bütünü meydana getirmektedir. Posterde genel manada gösterilen, Alman nüfusunun artışı veya mevcut nüfusun korunması için ülke dışından gelen göçmenlere ihtiyacın olmadığıdır. Almanlar nüfuslarını kendileri koruyabilmektedir. $\mathrm{Bu}$ açıdan diğer partilerin göçmenlere yönelik "yeni iş gücü", "nüfusun dengelenmesi" ve "Alman toplumu için canlılık" gibi olumlu tezlerin çürütülmesi amaçlanmaktadır. Posterde gösterilen, Almanların kimseye ihtiyacı olmadığı, posterde yazan "selber/kendi bașına" yazısı ile vurgulanmakta, Almanların kendi işini kendi başına görebildiği açıklanmaya çalışılmıştır.

Tablo 4: AfD’nin “Yeni Almanlar” Konulu Propaganda Posteri ve Göstergeler Tablosu

\begin{tabular}{|l|l|l|}
\hline Göstergeler Sistemi \\
\hline Gösterge & Gösteren & Gösterilen \\
\hline İnsan & Hamile Kadın & Alman Halkının Çoğalması \\
\hline Eylem & Kadının Gülümsemesi & Geleceğe Dair Umut \\
\hline Yer & Kırlar & Mutluluk, Refah \\
\hline
\end{tabular}




\subsubsection{AfD'nin "Renkli Çeşitlilik" Konulu Propaganda Posteri'nin Göstergebilimsel Analizi}

AfD'nin "Renkli Çeşitlilik" konulu propaganda posterinde gösterge boyutunda üç kadının kullanıldığı görülmektedir. Kadınların Almanya'nın farklı eyaletlerini temsil eden yerel kıyafetler giydiği, iki kadının bir ellerini yumruk yaparak, baş parmaklarını kaldırdıkları "tamam/ sorun yok" anlamını ifade eden işaret yaptıkları, ortada bulunan kadının ise postere bakanlara el salladığı görülmektedir. Her üç kadının da yüzünde gülümseme vardır. Posterde kullanılan mekanda ise masmavi bir gökyüzünün yansıtıldığı görülmektedir. Posterin hemen üstünde ise Almanca “'Bunte Vielfalt?' Haben wir schon. / 'Renkli çeşitlilik mi?' Biz zaten öyleyiz" yazısı bulunmaktadır. Posterin hemen altında ise yine büyük harfler ile Almanca AfD'nin parti sloganlarından biri olan “TRAU DICH DEUTSCHLAND! / INAN ALMANYA!” yazısı bulunmaktadır. Posterin sağ alt bölümünde de AfD'nin parti logosu yer almaktadır.

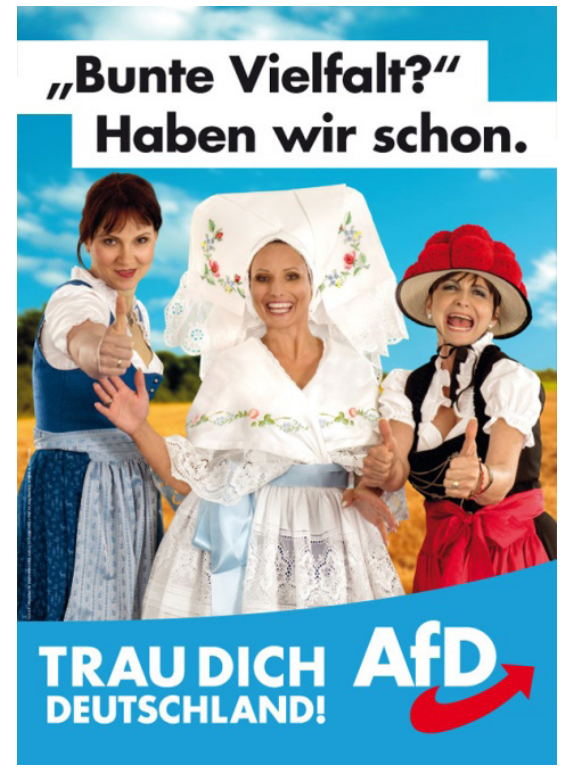

Resim 3: "Renkli Çeșitlilik" Konulu Propaganda Posteri

Kaynak: https://www.afd.de/meldungen-bundesverband/partnerportale/Erişim Tarihi: 04.02.2018.

Saussure'un Göstergeler Modeli üzerinden AfD'nin Renkli Çeşitlilik konulu propaganda posterinin analizinin yapılabilmesi için, posterin yayınlandığı dönemde Almanya'daki bağlamın çok iyi bir şekilde okunması gerekmektedir. Nitekim, AfD aşırı sağ eğilimli ve göçmen karşıtı politikalara sahip bir Alman partisidir. AfD'nin rakip olduğu partilerin bir kısmı ise göçmenlerin Almanya'ya gelişini desteklemektedir. $\mathrm{Bu}$ partiler göçmenlerin Almanya'da "kültürel renklilik" getireceği argümanını sürekli olarak belirtmektedirler. Nitekim, Almanya'nın farklı renkleri oluşturan bir mozaik olduğu, göçmenlerinde bu mozaiğin farklı renklerini meydana getirdiğini vurgulanmaktadırlar. Göçmenlerin Almanya'daki varlıklarını destekleyen bu partiler, Alman toplumunun kültürel zenginliğini olușturduklarını savunmaktadırlar.

Tablo 5: AfD'nin "Renkli Çeșitlilik" Konulu Propaganda Posteri ve Göstergeler Tablosu

\begin{tabular}{|l|l|l|}
\hline \multicolumn{2}{|l|}{ Göstergeler Sistemi } \\
\hline Gösterge & Gösteren & Gösterilen \\
\hline İnsan & Üç Kadın & Almanya'nın Farklı Kesimleri \\
\hline Yer & Mavi Gökyüzü & Mutluluk, Sevinç \\
\hline Eylem & Üç Kadının Gülümsemesi & Almanya'nın Refahı ve Huzuru \\
\hline
\end{tabular}


AfD’nin "Renkli Çeşitlilik" konulu propaganda posteri gösterilen boyutta doğru bir şekilde okunduğunda, posterin AfD’nin göçmenleri destekleyen siyasi partilere yönelik bir eleştirisini yansıttığı ortaya çıkacaktır. Nitekim, Almanya'da göçmenlerin "kültürel renklilik" oluşturduğu iddialarına karşı, AfD Almanya'nın zaten çok farklı kültürellerden oluştuğunun, her eyaletinin de birbirinden farklı kültürel öğelere sahip olduğunun vurgusu yapılmaktadır. Posterdeki sunum kodlarında yer alan üç kadının yerel kıyafetleri, AfD’nin bu iddiasının güçlü bir delili olarak gösterilmektedir. Posterde Saussure'ün gösterilen boyutunda inşa edilmek istenen algı, Alman halkının zaten kuzeyinden güneyine, doğusundan batısına çok farklı renklere ve kültürel değerlere sahip olduğu, Almanya'nın "kültürel renklilik" için göçmenlere ihtiyacı olmadığı şeklindedir. Posterde yer alan 'Renkli çeşitlilik mi?' Biz zaten öyleyiz” yazısı AfD’nin iddiasını direkt olarak ortaya koymaktadır. Özellikle posterde bulunan "schon/zaten, hali hazırda" yazısı, Almanya'nın zaten çok renkli olduğunu vurgulamaktadır. Posterdeki kadınların yüzlerindeki mutluluk, elleriyle yaptıkları "tamam" işareti ve arkalarında bulunan mavi gökyüzü diğer parçalarla birlikte bir bütün olarak yorumlandıklarında, posterdeki ana mesajın Alman halkının mutlu ve huzurlu olduğu, her şeyin zaten yolunda gittiği, göçmenlerin gelmesine Almanya'nın ihtiyaç duymadığıdır.

Son olarak, incelenen her üç posterin altında da AfD’nin “TRAU DICH DEUTSCHLAND! / İNAN ALMANYA!" şeklindeki propaganda sloganının yer aldığı görülmektedir. $\mathrm{Bu}$ sloganda AfD, posterdeki son mesajı ortaya koymaktadır. Posterdeki sunum kodlarında yer alan gösterilenler, seçmenler tarafından doğru bir şekilde okunduğunda, AfD "İnan Almanya!" sloganıyla seçmenin harekete geçmesini istemektedir. Almanya'daki mevcut durumun farkına varan seçmenin, artık AfD’yi desteklemesi gerektiği, çözümün AfD olduğu bu slogan ile vurgulanmaktadır.

\section{Sonuç}

Arap Baharı'ndan sonra Müslüman ülkelerden, Avrupa ülkelerine doğru yönelen göç dalgasının daha da büyüdüğü görülmektedir. Bu süreçte, Avrupa'daki hükümetler göçmenlere yönelik belirli yaptırımlar uygulamaya başlamış ve ülkelerine gelen göçmen sayısını sınırlama yoluna gitmiştir. Tüm bu yapılan çalışmalara karşın, hükümetlerin göçmenlere karşı yeterli önlem almadığını düşünen seçmenler göçmen karşıtı aşırı sağ fraksiyonları destekleme eğilimine girmişlerdir. Bu gruplar içerisinde Almanya'da 2013 yılında kurulan göçmen karşıtı AfD, 2017 Alman Federal Seçimleri'nde \%12,6'lık oy oranı elde etmeyi ve seçimde üçüncü parti olmayı başardı. AfD’nin beklenmedik başarısı, pek çok çevre tarafından Avrupa'da göçmenlere karşı oluşturulan kamuoyunun bir zaferi olarak yorumlandı. Bu süreçte, AfD’nin başarısında 2017 Alman Federal Seçimleri'nde yürüttügü başarılı propaganda kampanyasının etkili olduğu dünya basınında yer aldı. Buna karşın akademik alanda yapılan çalışmaların AfD’nin seçim zaferinde propaganda faktörünün nasıl bir rol oynadığını üzerinde durmadığı gözlemlenmiştir.

Bu çalışmada, kuruluşunun dördüncü yılında seçimlerde Almanya'nın en büyük üçüncü partisi olan AfD’nin başarısında, uyguladığı propaganda faaliyetlerinin rolü açıklanmaya çalışılmıştır. Çalışmada amaçlı örneklem metodu kullanılarak belirlenen AFD’nin 2017 Alman Federal Seçimleri'nde kullandığı göçmen karşıtı üç propaganda afişi ünlü İsviçreli Dil Bilimci Ferdinand de Saussure'ün Göstergeler Sistemi temelinde nitel araştırma yöntemlerinden göstergebilimsel analiz yöntemi kullanılarak incelenmiştir. Çalışma kapsamında elde edilen bulgular incelendiğinde, 
AfD’nin göçmen karşıtı politikalarda propaganda afişlerini etkin bir şekilde kullandığ gözlemlenmiştir.

AfD propaganda posterlerinde sunum kodları içerisindeki gösteren olarak kadınlara yervermiştir.Çalışmakapsamındaincelenenherüçpropagandaposterindedekadınlar posterlerin ana mesajını ileten gösterenler olmuştur. Çalışma kapsamında Alman toplumunu temsil eden kadınlar, genel olarak "huzur", "refah", "düzen","mutluluk" ve "istikrar" gibi olumlu metaforlar içerisinde kullanılmıştır. Çalışma kapsamında Alman toplumu için herhangi bir metonim kullanılma ihtiyacı duyulmamıștır. Buna karşın propaganda posterlerinin her üçünde de göçmenlere yer verilmemiş, ana mesajın göçmenlere karşı olduğu propaganda sloganları içerisinden okunabilmiştir. Sadece "Burkalar" konulu AfD’nin propaganda afişinde burkalar, göçmenleri ifade eden birer metonim olarak kullanılmıștır.

Propaganda posterlerinde AfD'de tarafından yeni algıların (Roland Barthes'ın deyimiyle yeni mitlerin) inşa edilmesi istenmiştir. Bunu gerçekleştirebilmek içinde, propaganda afişlerinde göçmenleri destekleyen partilerin oluşturduğu algıların yıkılması amaçlanmıştır. Uzun yıllardır Almanya'da göçmenlere yönelik inşa edilmeye çalışılan, "Almanlar nüfus yoğunluklarını koruyabilmek için göçmenlere ihtiyaç duyar",'Göçmenler Almanların farklı kültürel renkleridir",'Göçmenler Almanların mevcut düzenini yıkmaz" şeklindeki algılar AfD tarafından yok edilmeye çalışılmıştır.

Çalışma kapsamında incelenen "Burkalar" konulu posterde, "Göçmenlerin Almanya'daki mevcut düzeni yıkacağı”, "Yeni Almanlar” konulu posterde, "Almanya'nın nüfus istikrarı için göçmenlere ihtiyaç duymadığı", "Renkli Çeşitlilik" konulu poster de ise "Almanları zaten çok farklı kültürden oluştuğu, göçmenlere kültürel renklilik oluşturmada ihtiyaç duyulmadığı" ortaya konulmuştur.

Son olarak AfD’nin göçmen karşıtı propaganda posterleri üzerine genel bir incelemede bulunulduğunda, posterlerin Almanya'daki NPD (National Demokratische Partei Deutschlands), Avusturya'daki FPÖ (Die Freiheitliche Partei Österreichs), İsviçre'deki SVP (Die Schweizerische Volkspartei) gibi diğer göçmen karşıtı siyasi partilerden çok farklı bir propaganda dili kullandığı görülmüştür. NPD, FPÖ ve SVP'nin propaganda afişlerinde göçmen karşıtı mesajlar genel olarak korku çekiciliği kavramı temelli göçmenleri olumsuz göstermek üzerine kurgulanırken, AfD’nin sunum kodları içerisinde çok daha yumuşak bir propaganda dili içerisinde gösterilenleri ortaya koyduğu görülmüştür. AfD, göçmenleri "tehlike" metaforu üzerinden istenmeyen bir grup olarak değil, Almanların ihtiyaç duymadığı bir grup olarak propaganda posterlerinde sunmuştur. Bu açıdan seçmen zihninde radikal sağ bir fraksiyon olduğu imajını yok etmiş, sadece net göçmen karşıtı politikasıyla diğer partilere bir alternatif (partinin ismi de Almanya için Alternatif) olduğunu vurgulamıştır.

Bu çalışmada, AfD’nin 2017 Alman Federal Seçimleri'nde kullandığı göçmen karşıtı propaganda posterleri göstergebilimsel yöntem ışığında analiz edilmiştir. Elde edilen bulgular, Avrupa'da yükselen göçmen karşıtı hareketlerin propaganda faaliyetlerinin ortaya konulması bakımından alana ışık tutacağı düşünülmektedir. Buna karşın, incelemenin sadece AfD'nin propaganda posterleri üzerinden yapılması, çalışmanın önemli bir sınırlılığını oluşturmaktadır. Bu açıdan çalışma, diğer göçmen karşıtı partilerin propaganda faaliyetlerini yansıtmamaktadır. Gelecek 
çalışmaların Avrupa`daki diğer göçmen karşıtı partilerin propaganda faaliyetleri üzerine yoğunlaşmaları alana katkı sağlaması açısından önem arz edecektir.

\section{Kaynakça}

AfD. (2018). Erişim Tarihi: 04.02.2018. https://www. afd.de /meldungenbundesverband /partnerportale.

Barthes, R. (2016). Göstergebilimsel Serüven. (Çev. Mehmet Rifat-Sema Rifat). 8.Baskı. İstanbul:Yapı Kredi Yayınları.

Bebnowski, D. (2015). Die Alternative für Deutschland: Aufstieg und gesellschaftliche Repräsentanz einer rechten populistischen Partei. Springer-Verlag.

Bösch, F. (2002). Macht und Machtverlust. Die Geschichte der CDU. Stuttgart: Deutsche Verlags-Anstalt.

CDU (2018). Erişim Tarihi: 06.02.2018, https://www.cdu.de.

Der Spiegel. (2018). Erişim Tarihi: 04.02.2018. http:// www.spiegel.de / politik/ deutschland /bundestagswahl -2017- alle- ergebnisse-im -ueberblick-a-1167247.html //.

Deutsche Welle. (2018). Erişim Tarihi: 06.02.2018, http://www.dw.com/en/ afd-cdu-spd-where-do-german-parties-stand-on-refugees-asylum-andimmigration/a-40610988.

Die Linke,. (2018). Erişim Tarihi: 06.02.2018, https://www.die-linke.de.

Efkan, C. (1997). Hitler'den Torunlarına. İstanbul: Göçebe Yayınları.

FDP. (2018). Erişim Tarihi: 06.02.2018, https://www.fdp.de.

Geray, H. (2014). İletişim Alanından Örneklerle Toplumsal Araştırmalarda Nicel ve Nitel Yöntemlere Giriş. Kocaeli: Umuttepe Yayınları.

Grimm, R. (2015). The Rise of The German Eurosceptic Party Alternative Für Deutschland, Between Ordoliberal Critique and Popular Anxiety. International Political Science Review, 36(3), 264-278.

Gruene. (2018). Erişim Tarihi: 06.02.2018, https://www.gruene.de.

Guiraud, P. (2016). Göstergebilim. (Çev. Mehmet Yalçın). 3. Baskı. Ankara: İmge Kitabevi.

Işık, M. ve Eşitti, Ş. (2015). I. Dünya Savaşı Propaganda Afişlerinde Kadın Temsillerinin Toplumsal Cinsiyet Bağlamında Göstergebilimsel İncelenmesi. Ankara Üniversitesi SBF Dergisi, 70(3).

Kissinger, H. (2010). Diplomasi. (Çev. İbrahim H.Kurt). 9. Baskı. İstanbul: Türkiye İş Bankası Yayınları.

Kocabay, H. K. (2008). Tiyatroda Göstergebilim.Birinci Basım. İstanbul: E Yayınları.

Liddell Hart, B. (2015). İkinci Dünya Savaşı Tarihi (Çev. Kerim Bağrıaçı). İstanbul: Türkiye İş Bankası Yayınları.

Niedermayer, O. (2015). Eine neue Konkurrentin im Parteiensystem? Die Alternative für Deutschland. In Die Parteien nach der Bundestagswahl 2013 (pp. 175207). Springer Fachmedien Wiesbaden. 
NPD. (2018). Erişim Tarihi: 07.02.2018, https://www.npd.de.

Rıfat, M. (2013). Açıklamalı Göstergebilim Sözlügü: Kavramlar, Yöntemler, Kuramcılar, Okullar. İstanbul:Türkiye İș Bankası Kültür Yayınları.

Rıfat, M., Rıfat, S., Koş, A., \& Tekgül, D. (2010). Göstergebilim, Dilbilim ve Çeviribilim Terimleri Sözlüğü. İstanbul:Sel Yayınları.

Schmitt-Beck, R. (2014). Euro-Kritik, Wirtschaftspessimismus und Einwanderungsskepsis: Hintergründe des Beinah-Wahlerfolges der Alternative für Deutschland (AfD) bei der Bundestagswahl 2013. Zeitschrift für Parlamentsfragen, 94-112.

Schmitt-Beck, R. (2017). The 'Alternative für Deutschland in The Electorate': Between Single-İssue and Right-Wing Populist Party. German Politics, 26(1), 124-148.

Sığırcı, İ. (2016), Göstergebilim Uygulamaları, Metinleri, Görselleri ve Olayları Okuma. Ankara:Seçkin Yayıncılık.

SPD. (2018). Erişim Tarihi: 06.02.2018, https://www.spd.de.

Tanyeri Mazıcı, E. ve Çakı, C.(2018). Adolf Hitler'in Korku Çekiciliği Bağlamında Kamu Spotu Reklamlarında Kullanımı. Erciyes İletişim Dergisi, 5 (3), 290-306.

United Nations. (2018). Erişim Tarihi: 04.02.2018. https:/ /www .un.org/ en / development /desa/population /migration /data /estimates2/estimates15. shtml.

Zorlu, Y., Çakı, C., \& Karaca, M. (2017). Türk Sinemasında Nazizm İdeolojisi: "Kırımlı" Filmi Ve Göstergebilimsel Analizi. Sosyoloji Konferansları, (56), 67. 